\title{
Murine model of surgically induced acute aortic dissection type A
}

\author{
Peter Matt, MD, ${ }^{\mathrm{a}, \mathrm{b}, \mathrm{c}}$ David L. Huso, DVM, PhD, ${ }^{\mathrm{d}}$ Jennifer Habashi, MD, ${ }^{\mathrm{c}}$ Tammy Holm, MD, ${ }^{\mathrm{c}}$ \\ Jeff Doyle, MD, ${ }^{\mathrm{c}}$ Florian Schoenhoff, MD, ${ }^{\mathrm{b}, \mathrm{c}, \mathrm{e}}$ Guosheng Liu, ${ }^{\mathrm{d}}$ James Black, MD, ${ }^{\mathrm{c}}$ \\ Jennifer E. Van Eyk, PhD, ${ }^{b}$ and Harry C. Dietz, $M^{c}$
}

\begin{abstract}
Objectives: This study aimed at developing a murine model of surgically induced acute aortic dissection type A for investigation of the formation and progression of acute aortic dissection and to test whether this system could be used for biomarker discovery.
\end{abstract}

\begin{abstract}
Methods: Adult fibrillin-1 deficient, $\mathrm{FbnI}^{\mathrm{ClO} 1039 \mathrm{G} / \mathrm{H}}$ mice and wild-type mice were anesthetized, ventilated, and the ascending aorta exposed via hemisternotomy. We hypothesized that acute aortic dissectiion could be induced either by injecting autologous blood into the aortic wall or by injury to the wall with aortic clamping. Echocardiography was done preoperatively, and serum samples were collected before and 30 minutes after the operation and analyzed by enzyme-linked immunosorbent assay.
\end{abstract}

Results: Echocardiography revealed larger aortic root diameters in $\mathrm{Fbnl}^{\mathrm{ClO} 9 \mathrm{GG} / \mathrm{t}}$ compared with wild-type mice $(P=.001)$. Histologic examination showed that aortic clamp injury but not injection of blood leads to large intimal tears, disruption of aortic wall structures, and localized dissection of the aortic media in $\mathrm{FbnI}^{\mathrm{ClO} 39 \mathrm{G} / \mathrm{H}}$ mice. Acute aortic dissection developed in 4 of $5 \mathrm{Fbnl} \mathrm{ClO39G/4}^{\mathrm{m}}$ mice versus 0 of 5 wild-type mice after aortic clamping $(P<.01)$. Elastin staining showed higher elastic fiber fragmentation and disarray in $F b n 1^{C 1039 G / 4}$ compared with wild-type mice. Enzyme-linked immunosorbent assay analysis revealed elevated circulating transforming growth factor $\beta 1$ concentrations after induction of acute aortic dissection in $F b n I^{C 1039 G / 4}$ mice $(P=.02$, $150 \pm 61 \mathrm{ng} / \mathrm{mL}$ vs $456 \pm 97 \mathrm{ng} / \mathrm{mL}$ ), but not in wild-type or sham-operated mice.

Conclusions: Aortic clamp injury can induce AAD in $\mathrm{Fbnl}^{\mathrm{Cl039G/4}}$, but not in wild-type mice. This murine model of surgically induced acute aortic dissection is highly reproducible and nonlethal in the short term. Using this system, we revealed that circulating transforming growth factor $\beta 1$ is a promising biomarker for acute aortic dissection. (J Thorac Cardiovasc Surg 2010;139:1041-7)

Acute dissections involving the ascending aorta (AAD) are life-threatening conditions with high morbidity and mortality even after emergency surgery. ${ }^{1,2}$ AAD develops often in persons older than 40 years, reflecting their increased rates of arterial hypertension and atherosclerosis. ${ }^{3}$ Other predisposing factors, especially in younger patients,

\footnotetext{
From the Division of Cardiac Surgery, University Hospital Basel/Berne, Switzerland ${ }^{\text {a }}$; Johns Hopkins Proteomics Center, ${ }^{\mathrm{b}}$ Howard Hughes Medical Institute and Institute of Genetic Medicine ${ }^{c}$ and Department of Molecular and Comparative Patho-

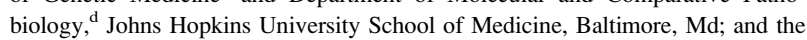
Department of Cardiovascular Surgery, ${ }^{\mathrm{e}}$ University Hospital Berne, Switzerland.

Disclosures: Peter Matt thanks the Swiss National Foundation, the Novartis Foundation, and the Hippocrate Foundation Basel for financial support. Jennifer E. Van Eyk is supported by grants from the National Heart, Lung, and Blood Institute Proteomic Initiative (contract NO-HV-28120), the Daniel P. Amos Family Foundation and the Institute for Clinical, and Translational science Award (Grant NO 1U54RR023561-01A1). Harry C. Dietz is supported by the National Institutes of Health, the Howard Hughes Medical Institute, the William S. Smilow Center for Marfan Syndrome Research and the National Marfan Foundation. James Black is supported by the John J. Roberts Aortic Research Fund.

Received for publication May 10, 2009; revisions received July 12, 2009; accepted for publication Aug 9, 2009; available ahead of print Nov 12, 2009.

Address for reprints: Peter Matt, MD, Division of Cardiac Surgery, University Hospital, Spitalstrasse 21, CH-4031 Basel, Switzerland (E-mail: pmatt@uhbs.ch) or David L. Huso, DVM, PhD, Department of Molecular and Comparative Pathobiology, Johns Hopkins Medicine, Baltimore, MD 21239. (E-mail: dhuso1@jhmi.edu). $0022-5223 / \$ 36.00$

Copyright (c) 2010 by The American Association for Thoracic Surgery doi:10.1016/j.jtcvs.2009.08.039
}

include pre-existing aortic aneurysm, aortic wall trauma, and connective tissue disorders such as Marfan syndrome (MFS). ${ }^{4}$ MFS is an autosomal dominant inherited disorder caused by mutations in the gene encoding the extracellular matrix protein fibrillin-1 and dysregulated transforming growth factor $\beta$ (TGF $\beta){ }^{5,6}$ Numerous theories about the process that initiates an AAD exist; however, it is uncertain whether the initiating event is a primary rupture of the intima with secondary dissection of the media or hemorrhage within the media and subsequent rupture of the overlying intima. Further understanding of molecular mechanisms leading to and associated with the formation and progression of an AAD are needed to gather novel insights and improve diagnostic and therapeutic strategies. The current indication for preventive surgical intervention is an aortic root diameter measuring $5 \mathrm{~cm}$. However, a majority of patients in whom aortic dissection or rupture develops never reach the $5-\mathrm{cm}$ diameter standard. ${ }^{7}$ Therefore, there is an urgent need for the development of new parameters or surrogate markers to more accurately identify impending aortic dissection or rupture. Studying AAD in humans is limited because most patients are seen after the dissection has occurred, and patients are mostly at different stages of the disease. A general difficulty in human studies is the wide interindividual 


\section{Abbreviations and Acronyms \\ $\mathrm{AAD}=$ acute aortic dissection \\ ELISA $=$ enzyme-linked immunosorbent assay \\ MFS $=$ Marfan syndrome \\ TGF $\beta=$ transforming growth factor $\beta$ \\ VVG $=$ Verhoeff-van Gieson}

variation in tissue specimens (eg, aortic tissue, serum, and plasma) and in external conditions that preclude a precise analysis of disease mechanisms. Small animal models for AAD could be used to exclude those factors and facilitate a more exact, standardized approach to studying the development and propagation of aortic dissection. Several murine and rat models of spontaneous aortic dissection have been described, but these systems are either transgenic or chemically induced and do not allow prediction of the time point at which the dissection occurs. ${ }^{8-12}$ We hypothesized that such a prediction could be made only if the AAD was surgically induced. A murine model of MFS that is heterozygous for a mutant fibrillin-1 allele, Fbn1 ${ }^{\text {C1039G/4 }}$, and develops progressive aortic root dilatation with sporadic dissections throughout life, might be predisposed to the development of an AAD after surgical manipulation. ${ }^{5,13}$ The goal of our study was to develop a reproducible and in the short-term nonlethal murine model of a surgically induced AAD that could be used to discover candidate biomarkers relevant to dissection.

\section{MATERIALS AND METHODS Animals}

The animals used in this study were 10-month-old female mice harboring Fbnl mutations, Fbn1 ${ }^{\text {C1039G/4 }}(\mathrm{n}=10)$, as described previously, ${ }^{13,14}$ and age-matched wild-type littermates $(\mathrm{n}=10)$. All analyses on Fbn1 C1039G/4 mice were done after back-crossing this mutation into the $\mathrm{C} 57 \mathrm{BL} / 6 \mathrm{~J}$ background ( $>9$ generations). In addition, adult Sprague-Dawley (CD) rats (Charles River Laboratories, Wilmington, Mass) $(\mathrm{n}=3)$ were used. All animals were treated and cared for in accordance with the National Institutes of Health's "'Guide for the Care and Use of Laboratory Animals"' (National Research Council, Washington, 1996), and all protocols were approved by the Animal Care and Use Committee at the Johns Hopkins University School of Medicine, Baltimore, Maryland.

\section{Surgical Procedure}

Anesthesia was induced by placing the animal in a closed induction chamber supplied with $2.5 \%$ isoflurane. Rats were not intubated but breathed spontaneously through a mask connected to a vaporizor (VetEquip, Inc, Pleasanton, Calif). The mice, once anesthetized, were transferred to the operating table (Rodent WorkStand; Braintree Scientific Inc, Braintree, Mass) in a supine position and orally intubated (Braintree Scientific) using microsurgical loupes with $3.5 \times$ magnification (Design for Vision, Ronkonkoma, NY). The endotracheal tube was connected to a rodent ventilator (Hugo-Sachs, March, Germany) set at 250 respirations/min with a $200-\mu \mathrm{L}$ tidal volume. Isoflurane was set at $2.5 \%$ in a $100 \%$ oxygen mix for the remainder of the procedure for mice and rats. For all surgical procedures, a surgical microscope (Microsurgery Instruments Inc, Bellaire,
Tex) was used. First, the right femoral vein was dissected and prepared for later collection of preclamping blood samples. A small upper sternal incision was made, the muscle layers on the right parasternal side were divided sharply, and a transverse sternotomy was performed at the height of the third intercostal space. The mediastinum was entered and a small retractor was positioned to provide appropriate access. The pericardium was opened, and the ascending aorta was exposed (Figure 1, A). Blood samples were then collected from the right femoral vein. In a first attempt to develop a surgical technique to induce the $\mathrm{AAD}$, autologous blood was injected into the ascending aortic wall of $\mathrm{Fbnl}^{\mathrm{ClO39G/+}}$ and wild-type mice and rats using microinjection needles (33-36 gauge; World Precision Instruments, Sarasota, Fla). Alternatively, mice received an aortic clamp injury just above the sinotubular junction using a microsurgical needleholder (Microsurgery Instruments Inc) (Figure 1, A). The injury was made by partially clamping the aortic wall for 0.5 to 1 second until a hematoma was visible (Figure 1, B). The sternum was then closed with 5-0 silk intercostal sutures, and the remaining divided muscle layers and skin were closed with a running 6-0 silk suture. After 30 minutes under anesthesia, the sternum was reopened and a postprocedure blood sample was collected from the right atrium. All mice and rats were humanely killed. Two Fbn1 ${ }^{\text {C1039G/4 }}$ and 2 wild-type mice underwent a sham operation with blood sample collection as controls.

\section{Tissue and Histologic Studies}

After the animals were humanely killed, the thoracic aorta and the attached heart were harvested and immediately fixed in $10 \%$ buffered formalin. For further analysis, the fixed aorta was processed and embedded in paraffin, sectioned at $5 \mu \mathrm{m}$, and stained with hematoxylin and eosin or Verhoeff-van Gieson (VVG; elastin) for analysis by conventional light microscopy. VVG-stained sections of the ascending aorta in $\mathrm{Fbnl}^{\mathrm{ClO}} \mathrm{gGG/4}$ mice at 1 month, 4 months, and 9 months of age were analyzed for comparative histologic features over time.

\section{Serum}

All blood samples, immediately before and 30 minutes after the aortic injury, were allowed to clot for 2 hours at room temperature before being centrifuged for 20 minutes at $2000 \mathrm{~g} .{ }^{15}$ Serum was removed, divided into aliquots, and immediately frozen and stored at $-80{ }^{\circ} \mathrm{C}$ until further analysis.

\section{Enzyme-Linked Immunosorbent Assay (ELISA) for TGF $\beta$}

TGF $\beta 1$ concentrations were measured in serum samples by ELISA using the Quantikine TGF $\beta 1$ immunoassay (R\&D Systems, Minneapolis, Minn, catalog No. MB100M). The minimum detectable dose of TGF $\beta 1$ in this assay ranges from 1.7 to $15.4 \mathrm{pg} / \mathrm{mL}$, and there is less than $1 \%$ (MB100M) cross-reactivity with the latent TGF $\beta 1$ complex. Total TGF $\beta 1$ concentrations were measured by first acid activating (with $1 \mathrm{~N}$ hydrogen chloride) latent $\mathrm{TGF} \beta 1$ to immunoreactive $\mathrm{TGF} \beta 1$. The ELISA was performed according to the manufacturer's protocol. In brief, the wells were precoated with capture monoclonal antibody specific for TGF $\beta 1$. Standards, controls, and samples were added and incubated for 2 hours. After washing, an enzyme-linked polyclonal detection antibody specific for TGF $\beta 1$ was added. After another washing, samples were incubated with a substrate solution for 30 minutes and the color reaction was stopped by addition of a dilute hydrogen chloride solution. The optical density of each well was measured immediately with a microplate reader at $450 \mathrm{~nm}$; the wavelength correction was set to $570 \mathrm{~nm}$. All samples were run in duplicate. We considered the results valid when recovery (expected concentration divided by calculated concentration multiplied by 100) of the standards/calibrators was $100 \% \pm 20 \%$, the coefficient of variation was less than $20 \%$, the intra-assay coefficient of variation was less than $10 \%$, and the interassay coefficient of variation was less than $20 \%$. A run was considered valid when more than $85 \%$ of samples were within these specifications. 

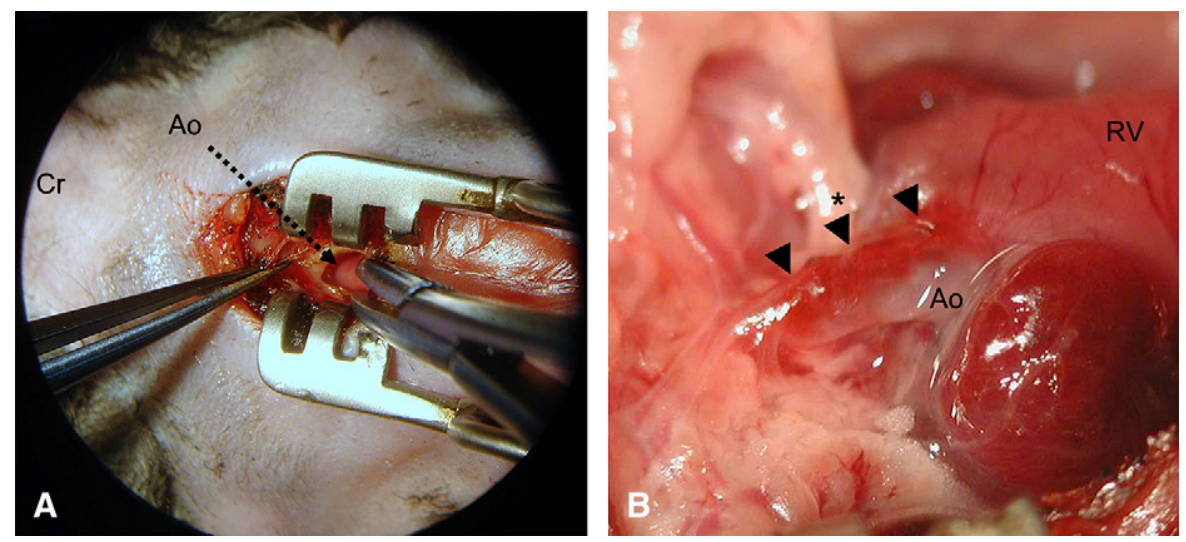

FIGURE 1. A, Intraoperative view through the dissecting microscope (Microsurgery Instruments Inc) showing the surgical approach through an upper partial sternotomy and the opened pericardium in a $\mathrm{Fbnl}^{\mathrm{C1039G/4}}$ mouse. The ascending aorta (tip of the arrow) was partially clamped with a microsurgical needleholder. B, Macroscopic view of the ascending aorta 30 minutes after the aortic clamp injury in the $F b n 1^{\mathrm{ClO} 39 G / 4}$ mouse. The aortic dissection was induced by clamping in the middle part of the ascending aorta $(*)$. After the clamp injury, the hematoma and partially the dissection extended toward the aortic root and the distal ascending aorta (arrows). Ao, Ascending aorta; $\mathrm{Cr}$, cranial; $\mathrm{RV}$, right ventricle.

\section{Echocardiography}

Transthoracic echocardiography was performed on awake, unsedated 10-month-old $\mathrm{Fbnl}^{\mathrm{ClO} 039 \mathrm{G} / 4}$ mice $(\mathrm{n}=10)$ and age-matched wild-type mice $(\mathrm{n}=10)$ using the VisualSonics Vevo 660 V1.3.6 imaging system and a $40-$ or $60-\mathrm{MHz}$ transducer (model RMV603, VisualSonics Inc, Toronto, Ontario, Canada). The aorta was imaged in the parasternal longaxis view, and 3 measurements were obtained at the level of the sinus of Valsalva by an observer blinded to genotype. All echocardiographic studies were performed by 2 individuals with extensive experience in mouse echocardiography.

\section{Statistical Analysis}

For statistical analysis, the Student $t$ test and Fisher's exact test were used as appropriate. Data are presented as mean \pm SEM. SPSS statistical software version 9.0 (SPSS, Inc, Chicago, Ill) was used for all analyses.

\section{RESULTS}

\section{Operative Observations}

Injection of autologous blood into the aortic wall of FbnI ${ }^{C 1039 G /+}$ and wild-type mice was difficult because of the small aortic wall dimensions (despite the 36-gauge microinjection needles) and the rapid pulse rate. In consequence, the reproducibility of the aortic wall hematoma was inconsistent, and there were only small intimal tears at the site of the injection. These aortic wall lesions did not resemble AAD as seen in humans. Injection of autologous blood into the aortic wall of adult Sprague-Dawley rats was much easier and resulted in reproducible and extensive periaortic wall hematomas. The aortic clamp injury performed surgically in $\mathrm{Fbnl}^{\mathrm{ClO} 103 \mathrm{G} / 4}$ and wild-type mice was highly reproducible. Whereas the clamping led in wild-type mice $(\mathrm{n}=5)$ only to a localized aortic wall hematoma, in $\mathrm{Fbnl}^{\mathrm{ClO39G/4}}$ mice $(\mathrm{n}=5)$ the aortic clamp injury resulted in massive localized aortic wall hematomas that separated the tunica media extending into the aortic root and the proximal part of the aortic arch (Figure 1, B). The extent of these lesions increased in proportion with the aortic root diameter. In addition, there were large intimal tears at the site of the clamping in $\mathrm{FbnI}^{\mathrm{ClO39G/4}}$ mice, but wildtype mice showed only small intimal lesions. No aortic rupture occurred in $\mathrm{FbnI}^{\mathrm{ClO39G/4}}$ and wild-type mice within 30 minutes after the operation.

\section{Histologic Studies}

Aortic sections stained with hematoxylin and eosin showed that injection of autologous blood into the aortic wall of wild-type rats results in large but strictly periaortic wall hematomas. There was no aortic media dissection in the histologic sections examined (not shown). After the aortic clamp injury, there were small intimal lesions in wild-type mice, and 2 of 5 wild-type mice had transmural lesions with blood within the adventitial layer, but no aortic media dissection occurred (Figure 2, A). In contrast, the aortic clamping in $\mathrm{Fbnl}^{\mathrm{ClO} 039 \mathrm{G} / \mathrm{H}}$ mice resulted in large intimal tears, a massive disruption of aortic wall structures, and in 4 of $5 \mathrm{Fbnl}^{\mathrm{ClO39G/+}}$ mice a break-up of the aortic medial layer with subsequent localized dissection and blood within the aortic media (Figure 2, $B$ to $D$ ).

Staining for elastin showed extensive disruption of elastic lamellae and elastin fibers at the site of the aortic clamping with large intimal tears in $\mathrm{Fbnl}^{\mathrm{ClO} O \mathrm{G} G / \mathrm{H}}$ mice (Figure 3, A to $D)$. There were localized aortic dissections with blood within the fragmented and disarrayed elastic fibers of the media layer (Figure 3, $A$ to $D$ ), resembling those seen in human Marfan-like AAD. ${ }^{3}$ All surgically induced aortic dissections in $\mathrm{Fbnl} \mathrm{ClO39G/4}^{\mathrm{C}}$ mice were localized around the aortic clamping area and limited to the ascending aorta. Comparative histologic studies with VVG staining of the ascending aorta in $\mathrm{FbnI}^{\mathrm{ClO} 9 \mathrm{G} / \mathrm{H}}$ mice at 1 month, 4 months, and 9 months of age showed progressive fragmentation and 


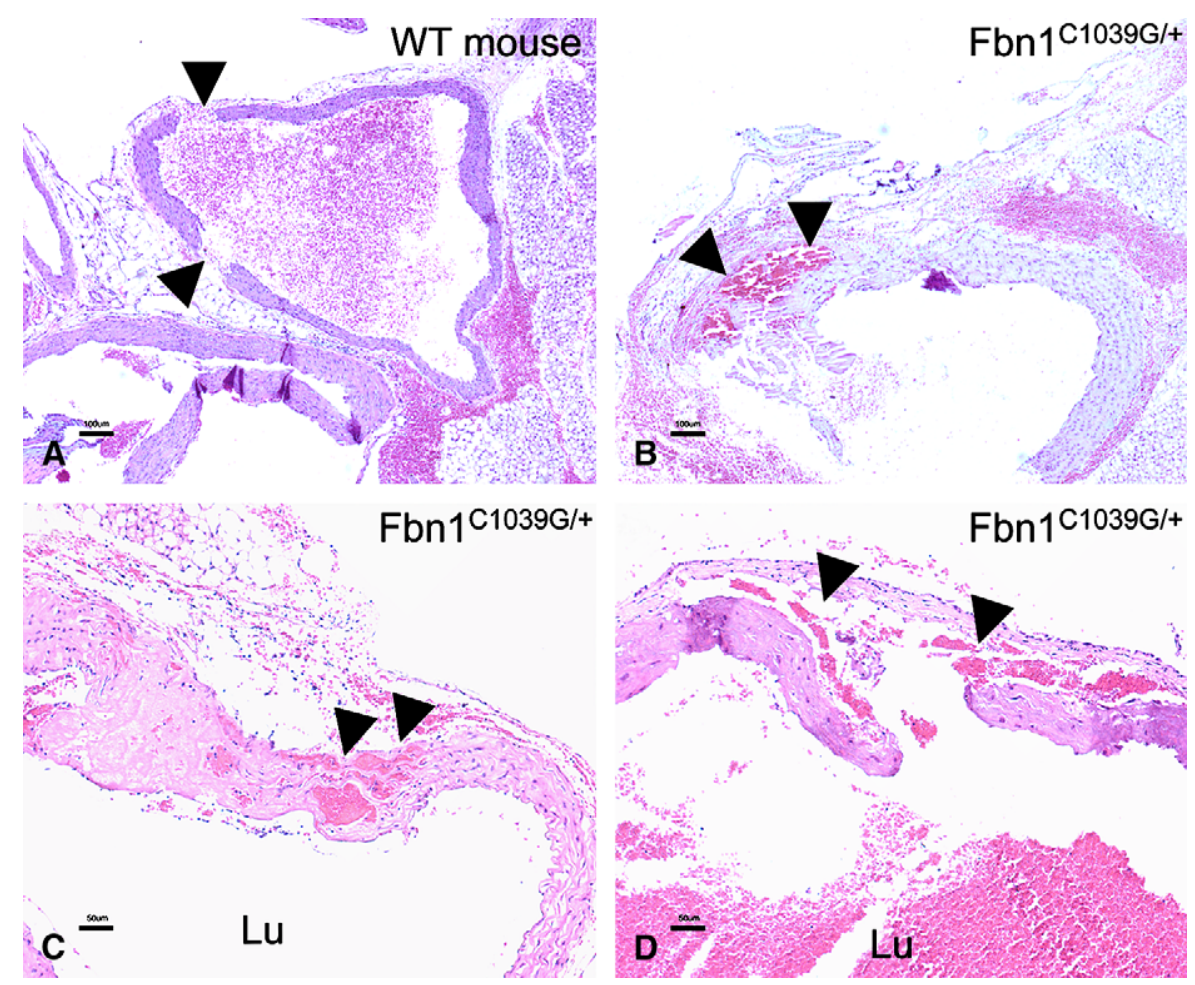

FIGURE 2. Histologic sections of the ascending aorta stained with hematoxylin and eosin. A, Aortic section in a wild-type mouse after the aortic clamp injury that led to transmural tears (arrows) and periadventitial hematoma, although no aortic media dissection occurred. B to D, In contrast, the clamp injury in $\mathrm{FbnI}^{\mathrm{ClO} 103 \mathrm{G} / \mathrm{H}}$ mice resulted in large intimal tears, disruption and break-up of the aortic medial layer with subsequent localized dissection, and blood within the aortic media (arrows). WT, Wild-type; $L u$, lumen of the vessel.

disarray of elastic fibers and increase in matrix deposition within the aortic media over time (Figure $4, A$ to $D$ ). VVG staining showed marked elastin fiber fragmentation and disarray in 10-month-old $\mathrm{Fbnl}^{\mathrm{ClO} 9 \mathrm{GG} /+}$ mice compared with age-matched wild-type mice (not shown).

\section{Aortic Root Diameters}

Transthoracic echocardiography revealed significantly larger sinus of Valsalva diameters in $\mathrm{Fbnl}^{\mathrm{C1039G/+}}(\mathrm{n}=$ 10) mice compared with age-matched wild-type $(\mathrm{n}=10)$ mice $(P=.001$; mean \pm SEM $2.12 \pm 0.08 \mathrm{~mm}$ vs $1.77 \pm$ $0.05 \mathrm{~mm})$.

\section{Circulating TGF $\beta$}

Circulating TGF $\beta 1$ concentrations in serum samples from $\mathrm{Fbnl}^{\mathrm{ClO39G/4}}$ mice $(\mathrm{n}=5)$ significantly increased by 30 minutes after induction of the $\operatorname{AAD}(P=.02$ [paired $t$ test]; mean \pm SEM $150 \pm 61 \mathrm{ng} / \mathrm{mL}$ vs $456 \pm 97 \mathrm{ng} /$ $\mathrm{mL})$ (Figure 5). In contrast, wild-type mice $(\mathrm{n}=5)$ showed no significant increase in circulating TGF $\beta 1$ levels after the aortic clamp injury $(P=.7 ; 82 \pm 54 \mathrm{ng} / \mathrm{mL}$ vs $112 \pm 48 \mathrm{ng} /$ $\mathrm{mL})$; similar results were found in sham-operated FbnI ${ }^{\mathrm{Cl039G/4}}(\mathrm{n}=2)$ mice and sham-operated wild-type $(\mathrm{n}=2)$ mice $(P=.7 ; 219 \pm 160 \mathrm{ng} / \mathrm{mL}$ vs $198 \pm 126$ $\mathrm{ng} / \mathrm{mL})$.

\section{DISCUSSION}

Several models of spontaneous aortic dissection in mice and rats have been described. ${ }^{8-12,16}$ Mice with hypomorphic or mutant fibrillin-1 alleles have proximal thoracic aortic aneurysm, aortic dissection, and rupture. ${ }^{16}$ Mice with a biglycan deficiency show dissection and rupture of the thoracic and abdominal aorta within the first 3 months of life. ${ }^{8}$ Biglycans play a critical role in the control of collagen fibrillogenesis and in the proper assembly of the extracellular matrix. In utero exposure to semicarbazide, an inhibitor of the vascular enzyme semicarbazide-sensitive amine oxidase, results in thoracic aortic aneurysm and dissection, but no rupture, in newborn rats. ${ }^{9}$ The postnatal administration of $\beta$-aminopropionitrile monofumarate, which induces vascular medial degeneration, fragmentation of elastic fibers, and apoptosis of vascular smooth muscle cells, leads to aortic dissection in rats by inhibiting the cross-linking of collagen fibers. ${ }^{10}$ Other authors report aneurysm formation and media dissection induced by angiotensin II infusion in apolipoprotein E-deficient mice or salt-sensitive aortic dissection in mice with overproduction of angiotensin. ${ }^{12}$ Although all these nonsurgical means to induce aortic dissection provide new insights into specific pathomolecular mechanisms of the disease, they are less useful for prospective studies of the formation and progression of AAD. In 


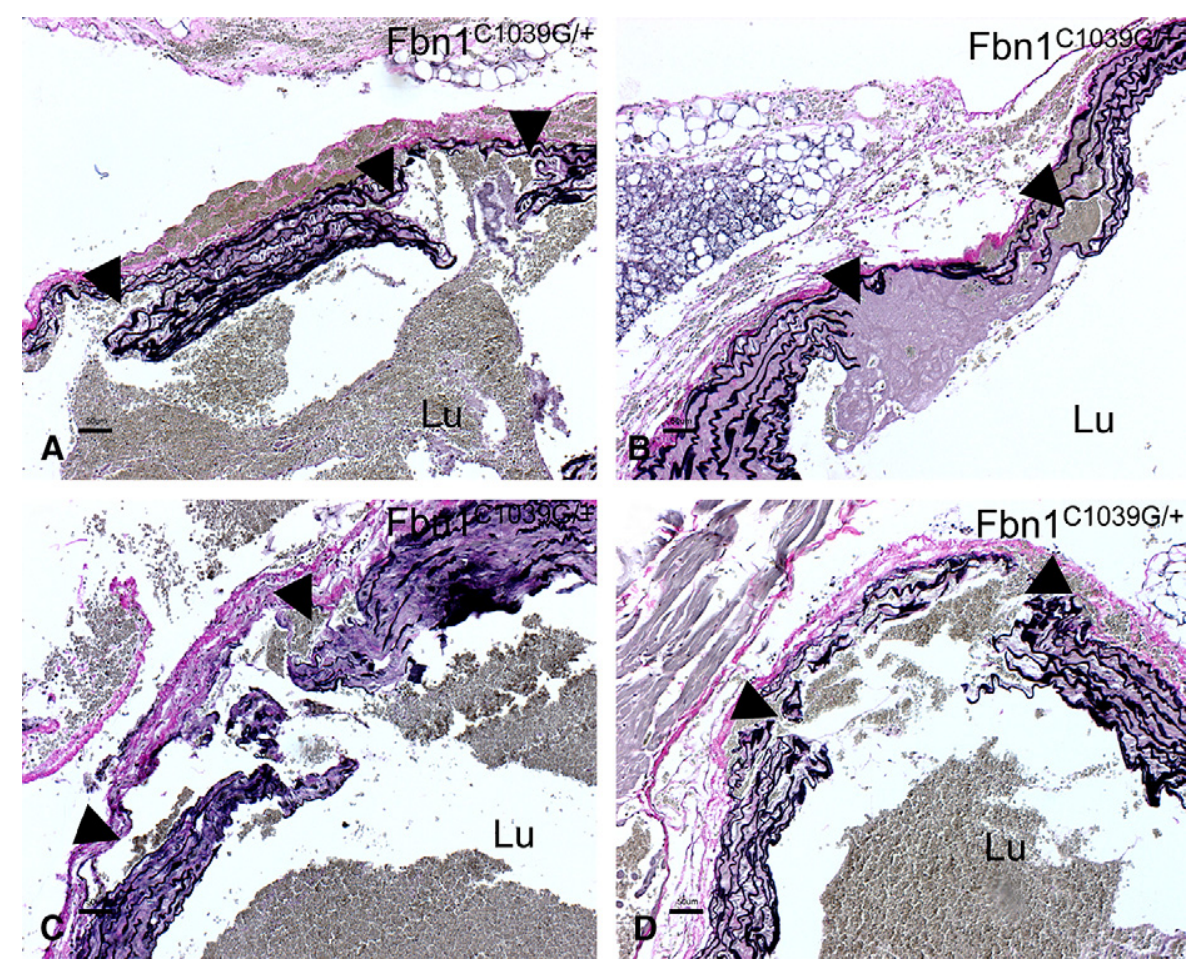

FIGURE 3. Sections of the ascending aorta stained with Verhoeff-van Gieson (VVG; elastin) in $\mathrm{Fbnl}^{\mathrm{ClO} 10 \mathrm{gG} / \mathrm{A}}$ mice. A to D, The aortic clamp injury led to extensive intimal tears, disruption of elastic fibers, and localized dissection with blood within the aortic medial layer (arrowheads). Lu, Lumen of the vessel.

addition, discovery of a specific biomarker might be difficult inasmuch as nonsurgical manipulations will result in a variety of alterations at the serum or plasma protein level not related to the aortic dissection.

We hypothesized that a small animal model could most consistently be achieved by inducing the AAD surgically. The initial hypothesis was that injecting autologous blood into the ascending aortic wall might be the most physiologic way to induce an AAD. We tested this technique using wild-type mice and mice heterozygous for a mutant $F b n I$ allele, FbnI ${ }^{\mathrm{ClO39G/4}}$, which is the most common class of mutation causing MFS in humans. ${ }^{13,17} \mathrm{Fbnl}^{\mathrm{ClO} 103 \mathrm{G} / 4}$ mice show an enlarged aortic root and ascending aortic dimensions beginning at 2 weeks of age with progression throughout life, but only sporadically do they have aortic dissection later in life. In contrast, homozygous $\mathrm{Fbnl}^{-1-}$ mice uniformly die of aortic dissection and rupture before postnatal day $15 .{ }^{13,18}$ In the present study, right-sided upper partial sternotomy provided excellent exposure of the ascending aorta. However, injection of autologous blood into the aortic wall of $F b n I^{C 1039 G / 4}$ and wild-type mice was technically difficult because of the small blood vessels and high pulse rates, and it did not lead to a reproducible aortic wall hematoma or dissection. Aortic wall lesions were small and did not resemble those seen in patients with AAD. We hypothesized that this technique might be much easier in Sprague-Dawley rats with their larger dimensions and slower pulse rates. Using this technique in the rats, we were able to inject autologous blood into the aortic wall, resulting in extensive and reproducible aortic wall hematomas. Unfortunately, histologic analysis revealed that those hematomas were most often in the periaortic tissue, and no dissection of the aortic media or intimal tearings occurred. The aortic wall tissue of rats was apparently too compact and stable to dissect after the manipulation. Although the injection approach did not initiate an aortic dissection in mice or rats, it led to the hypothesis that aortic clamp injury at the ascending aorta might induce AAD. The induction of dissection in humans after aortic clamping has been reported, although rarely. ${ }^{4}$ Using the approach described herein, we applied a short and partial aortic clamp injury to the ascending aorta in $\mathrm{FbnI}^{\mathrm{ClO39G/+}}$ and wild-type mice (Figure 1, A). This procedure was technically easy and consistently resulted in massive localized intramural aortic wall hematomas extending toward the aortic root and the proximal part of the aortic arch in $\mathrm{FbnI}^{\mathrm{ClO39G/4}}$ mice (Figure 1, B). Wild-type mice, however, were resistant to this type of intramural hematoma formation. At the site of the aortic clamp injury, there were large intimal tears in $\mathrm{FbnI}^{\mathrm{ClO} 9 \mathrm{GG} / \mathrm{H}}$ mice, but not in their wild-type counterparts. Histologic sections revealed that the aortic clamping in $\mathrm{FbnI}^{\mathrm{ClO} 9 \mathrm{G} / \mathrm{H}}$ mice resulted in a massive localized disruption of the intimal and aortic medial layer with subsequent break-up of the aortic media and localized 


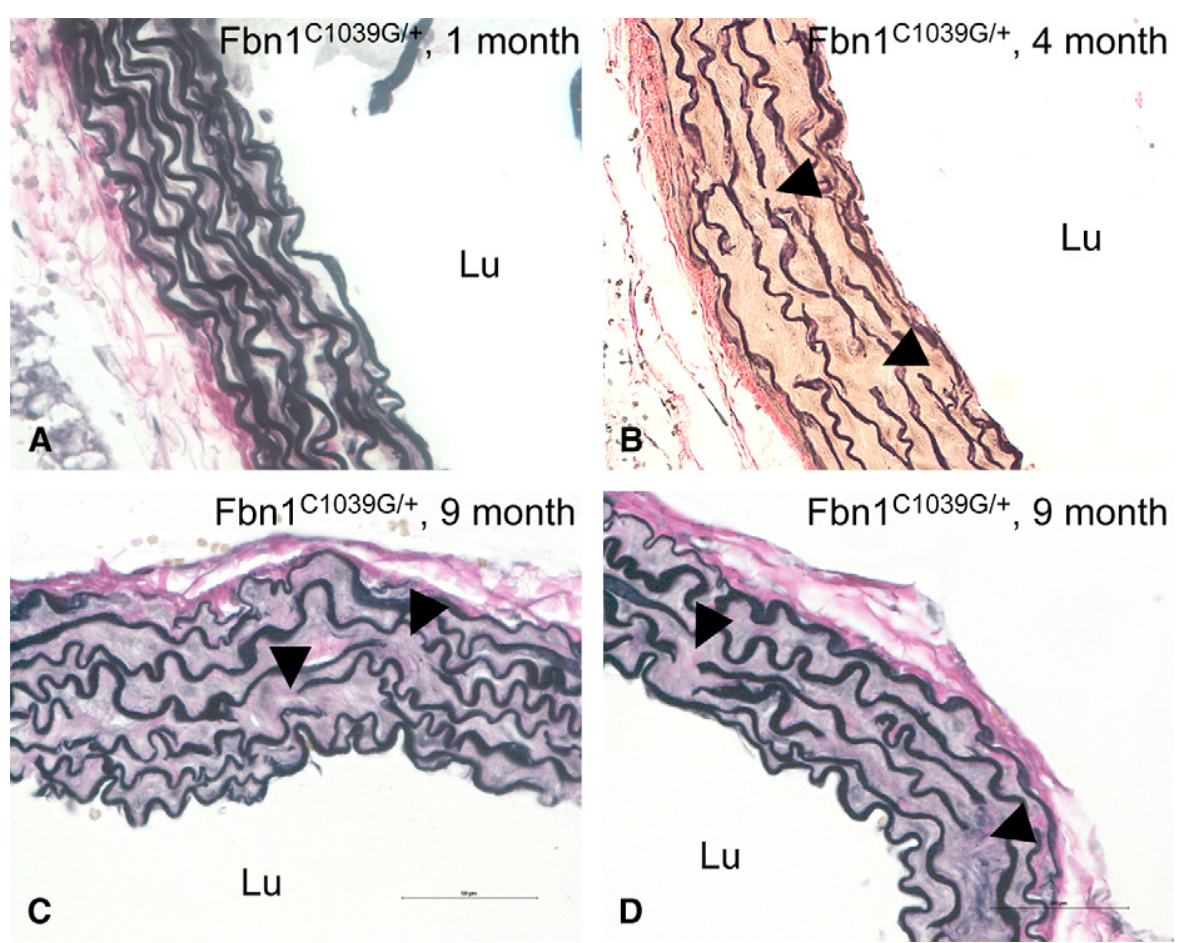

FIGURE 4. Sections of the ascending aorta stained with Verhoeff-van Gieson (VVG; elastin) in $F b n 1^{C 1039 G / 4}$ mice at 1 month, 4 months, and 9 months of age. Histologic sections show progressive fragmentation and disarray of elastic fibers (arrowheads) and increased matrix deposition within the aortic media over time. Although severe structural aortic wall changes already exist in 4-month-old $\mathrm{Fbnl}^{\mathrm{ClO} 9 \mathrm{G} / \mathrm{H}}$ mice, these lesions translate into progressive aortic root dilatation with increasing age and subsequently a predisposition for the development of aortic dissection. Lu, Lumen of the vessel.

dissection with blood within the fragmented and disarrayed elastic fibers in 4 of $5 \mathrm{Fbnl}^{\mathrm{ClO39G/4}}$ mice (Figure 2, B to D). These findings resembled those seen in patients with MFSlike AAD. ${ }^{3}$ Interestingly, the $F b n l^{C 1039 G / 4}$ mouse in which no dissection could be induced showed the smallest aortic root diameter among the studied $F b n l^{C 1039 G / 4}$ litters. In wild-type mice, there were some intimal tearings and transverse aortic lesions, but no dissection within the aortic media occurred. All surgically induced AADs in $\mathrm{Fbnl}^{\mathrm{ClO} 1039 \mathrm{G} / \mathrm{H}}$ mice were localized around the aortic clamping area and limited to the ascending aorta. There was no extension of the dissection to the aortic arch and the descending aorta, which might be due to the short postclamping time period studied (30 minutes). No $\mathrm{FbnI}^{\mathrm{ClO39G/4}}$ or wild-type mice died of rupture at the site of the aortic clamping. FbnI ${ }^{\mathrm{ClO} O 39 \mathrm{G} / \mathrm{H}}$ mice might be predisposed to the development of dissection after surgical manipulation because of their abnormalities within the aortic media. ${ }^{13}$ Histologic analysis showed higher elastin fiber fragmentation and disarray in $\mathrm{Fbnl}^{\mathrm{C1039G/4}}$ mice compared with age-matched wild-type mice, and those structural wall changes progress over time (Figure 4, $A$ to $D$ ), leading to enlarged aortic root diameter with increasing age. ${ }^{13}$ Further, longer-term survival studies are needed to analyze this novel murine model of surgically induced AAD, in particular to look at the progression of the dissection and whether it will extend to the descending and abdominal aorta. If so, this system would closely mimic aortic dissections seen in persons with MFS.

We tested whether the murine model could be used to discover novel, much needed candidate biomarkers for

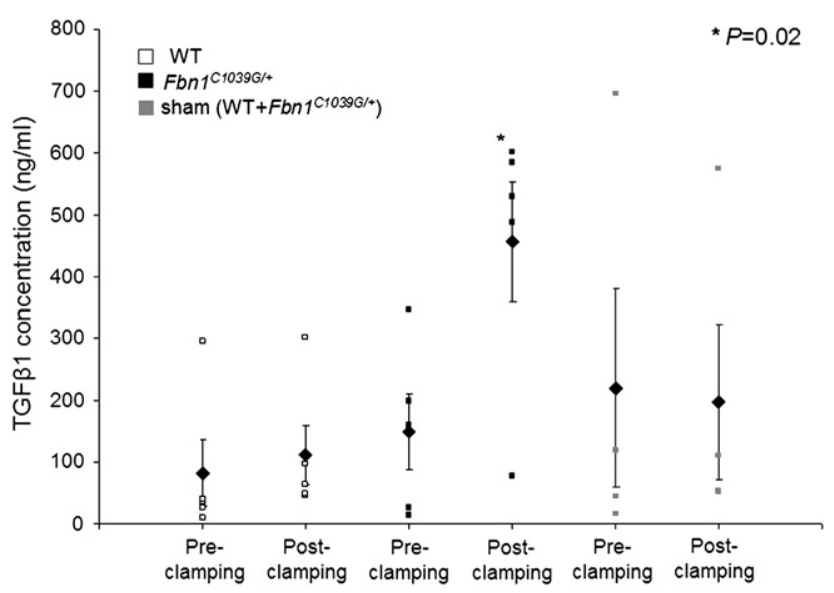

FIGURE 5. Circulating TGF $\beta 1$ serum concentrations in $\mathrm{Fbnl}^{\mathrm{C1039G/4} \text { and }}$ age-matched wild-type mice before (pre-clamping) and 30 minutes after (post-clamping) the aortic clamp injury. Circulating TGF $\beta 1$ levels significantly increased after induction of the AAD in $\mathrm{Fbnl}^{\mathrm{ClO39G/4}}$ mice $(P=$ .02 ), but not in wild-type mice and sham-operated litters. The graph shows each data point (square), mean values (rhombus), and SEM. 
diagnosis and monitoring of AAD. Serum samples were collected before and 30 minutes after the aortic clamp injury in $\mathrm{FbnI}^{\mathrm{ClO39G/4}}$ and wild-type mice and in shamoperated littermates. It was recently shown that dysregulated TGF $\beta$ plays a causal role in many of the multiorgan manifestations of MFS, including aortic root dilatation. ${ }^{13,19}$ There is excessive free TGF $\beta$ and $\operatorname{TGF} \beta$ signaling within the aortic root tissue of $\mathrm{Fbnl}^{\mathrm{ClO39G/+}}$ mice, which was also found in aortic specimen from patients with MFS. ${ }^{5,13}$ We hypothesized that the aortic clamp injury that leads to large intimal tearings and a break-up of the aortic medial layer with subsequent localized aortic dissection in $\mathrm{Fbnl}^{\mathrm{ClO39G/4}}$ mice might result in elevated circulating TGF $\beta$ concentrations. If so, circulating TGF $\beta$ levels should not increase in wild-type and sham-operated mice. Serum samples were analyzed by ELISA. The results revealed that circulating TGF $\beta 1$ levels indeed significantly increased 30 minutes after induction of the AAD in Fbnl ClO39G/4 $_{\text {mice }}$ (Figure 5). Interestingly, the Fbnl ${ }^{\text {C1039G/4 }}$ mouse in which no dissection could be induced showed the lowest preclamp and postclamp circulating TGF $\beta 1$ concentrations among the $\mathrm{Fbnl}^{\mathrm{Cl039G/4}}$ mice. Wild-type mice and sham-operated mice showed no change in circulating TGF $\beta 1$ levels. Therefore, it seems possible that TGF $\beta$ is a promising biomarker for AAD in MFS. This would be intriguing inasmuch as $\operatorname{TGF} \beta$ is a direct effector in pathomolecular mechanisms involved in aortic root disease in MFS. ${ }^{13}$ Further studies are clearly needed to validate circulating $\mathrm{TGF} \beta$ as a candidate biomarker relevant to dissection, determine whether it has the potential to improve diagnosis, and possibly even be used to predict aortic dissection in MFS. Other biomarkers for dissection have been described, for example, lactate dehydrogenase, smooth-muscle myosin heavy chain, soluble elastin fragments, C-reactive protein, or Ddimer. ${ }^{20-23}$ Unfortunately, the sensitivity and specificity of those markers is limited and no diagnostic blood test for aortic dissection is in routine clinical use to date. Therefore, we decided not to analyze those markers in the murine model. Our study presents circulating $\operatorname{TGF} \beta$ as a novel and promising biomarker for aortic dissection in MFS, and we report a murine model of surgically induced AAD that may assist further investigation and analysis in this field.

\section{References}

1. Hagan PG, Nienaber CA, Isselbacher EM, Bruckman D, Karavite DJ, Russman PL, et al. The International Registry of Acute Aortic Dissection (IRAD): new insights into an old disease. JAMA. 2000;283:897-903.

2. Masuda $\mathrm{Y}$, Yamada Z, Morooka N, Watanabe S, Inagaki Y. Prognosis of patients with medically treated aortic dissections. Circulation. 1991;84(5 Suppl). III7-13.
3. Marsalese DL, Moodie DS, Lytle BW, Cosgrove DM, Ratliff NB, Goormastic M, et al. Cystic medial necrosis of the aorta in patients without Marfan's syndrome: surgical outcome and long-term follow-up. J Am Coll Cardiol. 1990;16:68-73.

4. Svensson LG, Crawford ES. Aortic dissection and aortic aneurysm surgery: clinical observations, experimental investigations, and statistical analyses. Part II. Curr Probl Surg. 1992;29:913-1057.

5. Matt P, Habashi J, Carrel T, Cameron DE, Van Eyk JE, Dietz HC. Recent advances in understanding Marfan syndrome: should we now treat surgical patients with losartan? J Thorac Cardiovasc Surg. 2008;135:389-94.

6. Murdoch JL, Walker BA, Halpern BL, Kuzma JW, McKusick VA. Life expectancy and causes of death in the Marfan syndrome. N Engl J Med. 1972;286: 804-8.

7. Pape LA, Tsai TT, Isselbacher EM, Oh JK, O'Gara PT, Evangelista A, et al. Aortic diameter $>$ or $=5.5 \mathrm{~cm}$ is not a good predictor of type A aortic dissection: observations from the International Registry of Acute Aortic Dissection (IRAD). Circulation. 2007;116:1120-7.

8. Heegaard AM, Corsi A, Danielsen CC, Nielsen KL, Jorgensen HL, Riminucci M, et al. Biglycan deficiency causes spontaneous aortic dissection and rupture in mice. Circulation. 2007;115:2731-8.

9. Gong B, Trent MB, Srivastava D, Boor PJ. Chemical-induced, nonlethal, developmental model of dissecting aortic aneurysm. Birth Defects Res A Clin Mol Teratol. 2006;76:29-38.

10. Nagashima H, Uto K, Sakomura Y, Aoka Y, Sakuta A, Aomi S, et al. An angiotensin-converting enzyme inhibitor, not an angiotensin II type-1 receptor blocker, prevents beta-aminopropionitrile monofumarate-induced aortic dissection in rats. J Vasc Surg. 2002;36:818-23.

11. Daugherty A, Manning MW, Cassis LA. Angiotensin II promotes atherosclerotic lesions and aneurysms in apolipoprotein E-deficient mice. J Clin Invest. 2000; 105:1605-12.

12. Nishijo N, Sugiyama F, Kimoto K, Taniguchi K, Murakami K, Suzuki S, et al. Salt-sensitive aortic aneurysm and rupture in hypertensive transgenic mice that overproduce angiotensin II. Lab Invest. 1998;78:1059-66.

13. Habashi JP, Judge DP, Holm TM, Cohn RD, Loeys BL, Cooper TK, et al. Losartan, an AT1 antagonist, prevents aortic aneurysm in a mouse model of Marfan syndrome. Science. 2006;312:117-21.

14. Judge DP, Biery NJ, Keene DR, Geubtner J, Myers L, Huso DL, et al. Evidence for a critical contribution of haploinsufficiency in the complex pathogenesis of Marfan syndrome. J Clin Invest. 2004;114:172-81.

15. Matt $P$, Fu Z, Fu Q, Van Eyk JE. Biomarker discovery: proteome fractionation and separation in biological samples. Physiol Genomics. 2008;33:12-7.

16. Pereira L, Lee SY, Gayraud B, Andrikopoulos K, Shapiro SD, Bunton T, et al. Pathogenetic sequence for aneurysm revealed in mice underexpressing fibrillin1. Proc Natl Acad Sci U S A. 1999;96:3819-23.

17. Dietz HC, Cutting GR, Pyeritz RE, Maslen CL, Sakai LY, Corson GM, et al. Marfan syndrome caused by a recurrent de novo missense mutation in the fibrillin gene. Nature. 1991;352:337-9.

18. Ramirez F, Sakai LY, Dietz HC, Rifkin DB. Fibrillin microfibrils: multipurpose extracellular networks in organismal physiology. Physiol Genomics. 2004;19: 151-4.

19. Ng CM, Cheng A, Myers LA, Martinez-Murillo F, Jie C, Bedja D, et al. TGF-betadependent pathogenesis of mitral valve prolapse in a mouse model of Marfan syndrome. J Clin Invest. 2004;114:1586-92.

20. Suzuki T, Katoh H, Watanabe M, Kurabayashi M, Hiramori K, Hori S, et al. Novel biochemical diagnostic method for aortic dissection. Results of a prospective study using an immunoassay of smooth muscle myosin heavy chain. $\mathrm{Circu}$ lation. 1996;93:1244-9.

21. Shinohara T, Suzuki K, Okada M, Shiigai M, Shimizu M, Maehara T, et al. Soluble elastin fragments in serum are elevated in acute aortic dissection. Arterioscler Thromb Vasc Biol. 2003;23:1839-44.

22. Makita S, Ohira A, Tachieda R, Itoh S, Moriai Y, Yoshioka K, et al. Behavior of $\mathrm{C}$-reactive protein levels in medically treated aortic dissection and intramural hematoma. Am J Cardiol. 2000;86:242-4.

23. Eggebrecht H, Naber CK, Bruch C, Kroger K, von Birgelen C, Schmermund A, et al. Value of plasma fibrin D-dimers for detection of acute aortic dissection. J Am Coll Cardiol. 2004;44:804-9. 